Bangl. J. Vet. Med. (2008). 6 (2): 145-151

\title{
IMMUNOLOGICAL CHARACTERIZATION OF 37.81 kDa COMMON IMMUNODOMINANT SURFACE PROTEIN OF SOME SALMONELLA SEROVARS
}

\author{
F. Begum ${ }^{1}$, Y. Adachi ${ }^{1}$ and M. S. R. Khan ${ }^{2}$ \\ ${ }^{1}$ Animal Health Laboratory, School of Agriculture, Ibaraki University, Chuou, Ami, Ibaraki 300-0393, Japan \\ ${ }^{2}$ Department of Microbiology and Hygiene, Faculty of Veterinary Science, Bangladesh Agricultural University, \\ Mymensingh-2202, Bangladesh
}

\begin{abstract}
The research was performed for the immunological characterization of the $37.81 \mathrm{kDa}$ common immunodominant surface protein of some Salmonella serovars in order to examine the potency of that particular protein in terms of immunity production as well as withstood challenge exposure against virulent homologous and heterologous organism. The protective efficacy study in chicks gave protective levels of $40-50 \%$ in the heterologous challenge experiments and $50-60 \%$ in the homologous virulent challenge experiments. Therefore, the $37.81 \mathrm{kDa}$ surface protein might be useful at a certain level in control of salmonellosis in chicks.
\end{abstract}

Key words: Characterization, surface protein, Salmonella, chickens

\section{INTRODUCTION}

Salmonella infection is a serious medical and veterinary problem world-wide and causes great concern in the food industry. Meat of S. typhimurium DT104-infected cattle and pigs as well as poultry and eggs contaminated with S. enteritidis and S. typhimurium are responsible for acute gastroenteritis in humans (Carraminana et al., 1997, Solano et al., 1998, Schwartz, 1999). Fowl typhoid (Salmonella gallinarum) and Pullorum disease (S. pullorum) remain to cause economic losses in many countries where the poultry industries are continuing to develop and where open-sided housing is common (Mastroeni and menager, 2003). Prevention of the disease by implementation of hygienic measures is possible but difficult. Antibiotic treatment of the infection has been successful in the past, but new multi-drug-resistant Salmonella strains are rapidly emerging (Mastroeni and menager, 2003). Vaccination is an effective tool for the prevention of Salmonella infection. However, efficacy of currently available vaccines is not always enough (Mastroeni and menager, 2003).

Exposure to Salmonellae can result in antibody responses to a large number of antigens including lipopolysaccharide determinants (O-polysaccharide and core regions), porins, outer membrane proteins, lipoproteins, heat-shock proteins, flagella and fimbriae (Kuusi et al., 1979, Brown and Hormache, 1989, Matsui and Arai, 1989, Muthukkumar and Muthukkaruppan, 1993, Cooper and Thorns, 1996, Harrison et al., 1997, McSorley et al., 2000). The chemical and immunological characterization of a low molecular weight outer membrane protein (Omp-28) with 28-kDa and pl 4.6 which was isolated from S. typhi cells was reported (Andrade et al., 1998). The antisera from mice immunized with Omp-28 kDa gave a bactericidal activity to kill $50 \%$ of $S$. typhi cells in serum dilution of $1 / 80$ (Andrade et al., 1998). These studies demonstrated that immunological responses to Salmonella species dramatically varies on the basis of antigenic source and nature.

The interest of the present study was characterization of outer surface proteins of a wide variety of Salmonella serovars which possessed immunological activity to develop a suitable common vaccine for control Salmonellosis with a wide variety of Salmonella serovars and in various hosts. To achieve this purpose, a wellcharacterized and immunologically dominant common surface protein was important. The presence of the common surface protein of $37.81 \mathrm{kDa}$ among fifty four Salmonella serovars (Begum, 2005) raised a possibility that the $37.81 \mathrm{kDa}$ protein induced homologous or heterologous protective efficacy against the infection of Salmonella serovars. The common surface protein was characterized and used for immunization for a protective efficacy study. 


\section{MATERIALS AND METHODS}

The whole research work was performed in the Animal Health Laboratory, School of Agriculture, Ibaraki University, Ibaraki, Japan during the period of January 2004 to December 2004. Two hundred-day-old specific pathogen free (SPF) White Leghorn chicks (Average body weight: 33.91 $\pm 3.32 \mathrm{~g}$ ) were obtained from the National Institute of Animal Industry, Tsukuba, Japan. The chicks were divided into 4 groups, each group containing 50 chicks, and again subdivided into 5 groups, each group containing 10 chicks, of which one group was used as control. Each chick in each group was individually marked by tag in leg. The chicks were individually weighed and assigned to electrically heated pens. The pens were in a plastic isolator (A device for filtering the air for taking breath of chicks). The chicks were housed in a quiet and undisturbed room which was previously fumigated with formaldehyde. The chicks were reared with the supplement of antibiotic-free starter feed and tap water ad libitum.

NA-resistant Salmonella typhimurium L1338, Salmonella enteritidis A19, Salmonella cerro A12, and Salmonella johannesburg A28 were used for virulent challenge as well as a source of $37.81 \mathrm{kDa}$ protein. The $37.81 \mathrm{kDa}$ protein bands of Salmonella serovars described above were excised from the SDS-PAGE gels for purification according to the method of Miyazaki et al. (1994). Prior to immunization, the chick sera were checked for antibodies to Salmonella antigens by agglutination test. The chicks which were negative for Salmonella antibody were used for raising antibodies against the surface protein of $37.81 \mathrm{kDa}$.

Chicks were immunized according to the method of Tabaraie et al., (1994), with some modifications. Briefly, chicks were given intraperitonial (i/p) injection of $150 \mu \mathrm{g}$ of the $37.81 \mathrm{kDa}$ surface protein of the NA-resistant 4 Salmonella serovars. Primary and secondary immunizations were performed in 2-day-and 21-day-old chicks respectively. Blood samples of control and immunized chicks were collected at 2, 7, 14 and 21days of primary immunization. Similarly, blood samples were also collected from chicks at 7 and 14 days of secondary immunization. Control and immunized sera were used for agglutination test. The control and immunized chicks were challenged with challenge dose of virulent homologus and heterologus Salmonella serovars after 14 days of the secondary immunization.

The challenge dose was prepared according to the method of Nakamura et al., (2002) and Seo et al., (2002). Briefly, one colony of S. typhimurium L1338, S. enteritidis A19, S. cerro A12 and S. johannesburg A28 from the DHL agar containing $25 \mu \mathrm{g} / \mathrm{ml} \mathrm{NA}$, was transferred into $100 \mathrm{ml}$ of TSB and incubated for $24 \mathrm{~h}$ at $37^{\circ} \mathrm{C}$. The culture was then diluted 100 times with sterile TSB and $0.5 \mathrm{ml}$ of the diluted culture was inoculated orally into each group of chick. Instead of TSB only $0.5 \mathrm{ml}$ physiological saline was inoculated orally into control group. Thereafter, the $0.5 \mathrm{ml}$ TSB inocula were diuluted in saline $(0.85 \% \mathrm{NaCl})$, and spread on DHL agar. After $24 \mathrm{~h}$ incubation at $37^{\circ} \mathrm{C}$, the colony forming units were counted. The challenge dose was $S$. typhimurium $=5.8 \times 10^{6} ; S$. enteritidis $=7.5 \times 10^{6} ;$. cerro $=7.6 \times 10^{6} ;$. johannesburg A28 $=7.5 \times 10^{6}$.

Agglutination test was performed according to the method of Kashiwazaki et al., (1980), with slight modification. One colony of Salmonellae from DHL agar containing $25 \mu \mathrm{g} / \mathrm{ml}$ NA was cultured in $100 \mathrm{ml}$ of TSB. After incubation for $24 \mathrm{~h}$ at $37^{\circ} \mathrm{C}$, the culture was centrifuged at 9,500 rpm for $15 \mathrm{~min}$ at $5^{\circ} \mathrm{C}$. The precipitate was resuspended in $25 \mathrm{ml}$ of formalized saline $(0.85 \% \mathrm{NaCl}$ and $1 \%$ formaldehyde) for 4 -h at room temperature. Agglutination test was carried out as follows: $0.25 \mathrm{ml}$ of the formalized cell suspension was mixed with an equal volume of serially twofold dilution of a serum. After incubation for $2 \mathrm{~h}$ at $37^{\circ} \mathrm{C}$, agglutination was observed with a dark-field microscope at magnification of $\times 200$. Antibody titres were expressed as the maximum dilution of the serum giving $50 \%$ microscopic agglutination of the organism. Instead of a serum, physiological saline was used as negative control.

\section{RESULTS AND DISCUSSION}

The purity of protein was checked by SDS-PAGE using a 10\% separation gel (Fig. 1) and IB was performed for further confirmation (Fig. 2). Fig. 1 shows 10\% SDS-PAGE electrophoretic pattern of the $37.81 \mathrm{kDa}$ pure proteins from S. typhimurium L1338, S. Enteritidis A19, S. Cerro A12, S. johannesburg A28. Fig. 2 shows IB patterns of whole cell lysates and the pure $37.81 \mathrm{kDa}$ protein of S. typhimurium L1338, S. enteritidis A19, S. cerro A12, and S. johannesburg A 28. Fig. 1 showed the $37.81 \mathrm{kDa}$ pure protein was used for immunological response. Immunological responses after immunization of the pure $37.81 \mathrm{kDa}$ protein were detected by agglutination test with 4 Salmonella serovars (Table 1). 
Immunological characterization of Salmonella serovars

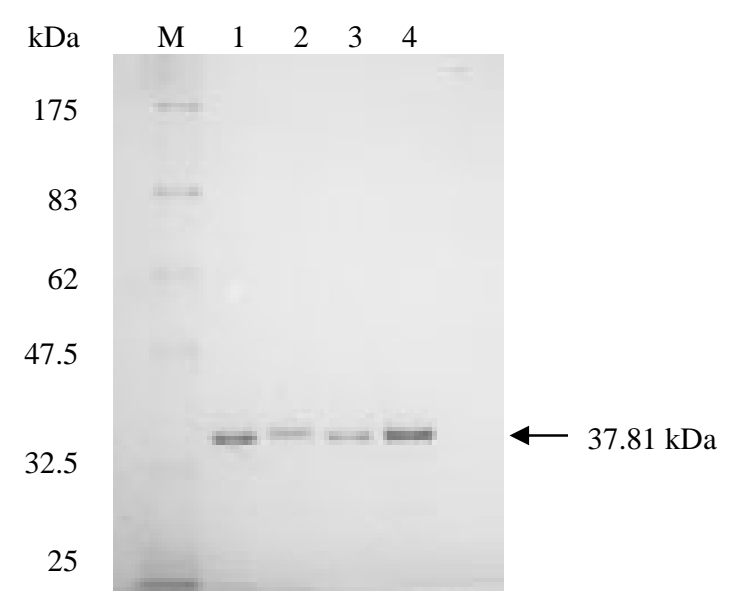

Fig. 1. SDS-PAGE of several pure $37.81 \mathrm{kDa}$ proteins. Lane 1, the $37.81 \mathrm{kDa}$ protein of S. typhimurium L1338; Lane 2, the $37.81 \mathrm{kDa}$ protein of S. enteritidis A19; Lane 3, the $37.81 \mathrm{kDa}$ protein of S. cerro A12; Lane 4, the $37.81 \mathrm{kDa}$ protein of $S$. johannesburg A28. Arrow indicates the $37.81 \mathrm{kDa}$. M, molecular size markers.

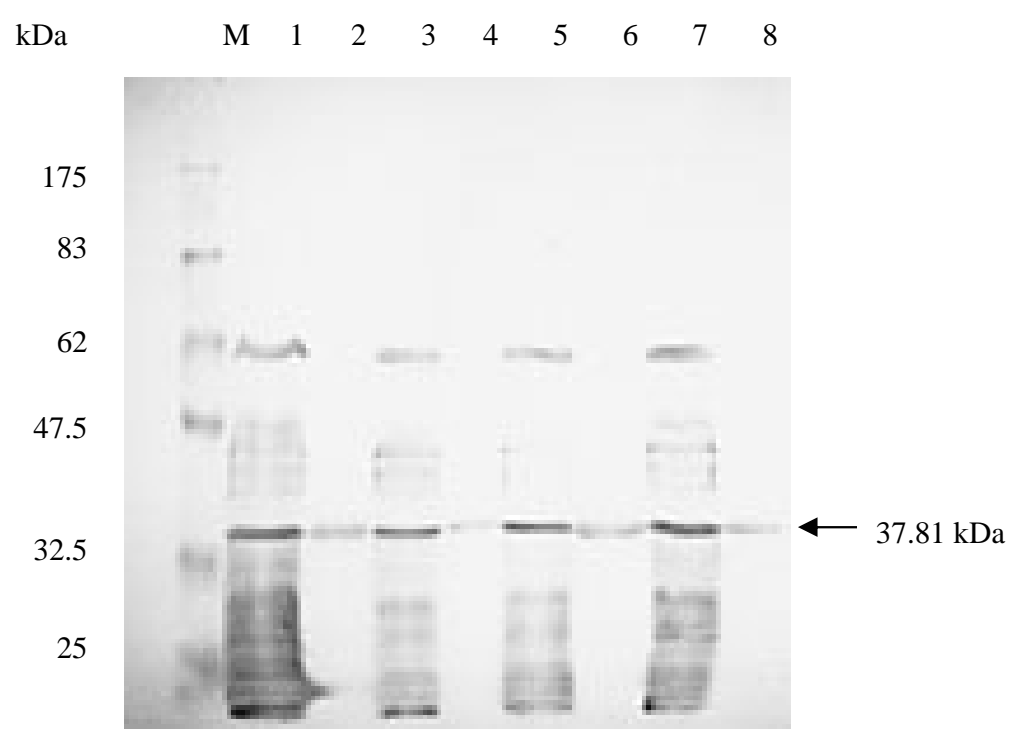

Fig. 2. IB reaction profiles of the pure $37.81 \mathrm{kDa}$ protein and several whole cell lysates of Salmonella serovars using the sera of chicks infected with S. typhimurium. Lane 1, S. typhimurium L1338; Lane 2, the $37.81 \mathrm{kDa}$ protein of S. typhimurium L1338; Lane 3, S. enteritidis A19; Lane 4, the $37.81 \mathrm{kDa}$ protein of S. enteritidis A19; Lane 5, S. cerro A12; Lane 6, the $37.81 \mathrm{kDa}$ protein of S. cerro A12; Lane 7, S. johannesburg A28; Lane 8, the $37.81 \mathrm{kDa}$ protein of $S$. johannesburg A28. Arrow indicates $37.81 \mathrm{kDa}$. M, molecular size markers. 
Table 1. Immunological response (Homologous reaction) by agglutination test after primary and secondary immunization with the pure $37.81 \mathrm{kDa}$ protein

\begin{tabular}{|c|c|c|c|c|c|}
\hline \multirow[t]{2}{*}{ Sera of } & \multirow[t]{2}{*}{ Days (Observation) } & \multicolumn{4}{|c|}{ Antigens } \\
\hline & & $\mathrm{ST}$ & SE & SC & SJ \\
\hline $\begin{array}{l}2 \text { dpi of primary } \\
\text { immunization }\end{array}$ & 2 & - & - & - & - \\
\hline $\begin{array}{l}7 \text { dpi of primary } \\
\text { immunization }\end{array}$ & 7 & - & - & - & - \\
\hline $\begin{array}{l}14 \text { dpi of primary } \\
\text { immunization }\end{array}$ & 14 & - & - & - & - \\
\hline $\begin{array}{l}21 \text { dpi of primary } \\
\text { immunization }\end{array}$ & 21 & \pm & \pm & \pm & \pm \\
\hline $\begin{array}{l}7 \text { dpi of secondary } \\
\text { immunization }\end{array}$ & 28 & \pm & \pm & \pm & \pm \\
\hline $\begin{array}{l}14 \text { dpi of secondary } \\
\text { immunization }\end{array}$ & 35 & + & + & + & + \\
\hline
\end{tabular}

-, no agglutination; +, more than 50\% agglutination; and \pm , less than $50 \%$ agglutination; ST, $S$. typhimurium L1338; SE, S. enteritidis A19; SC, S. cerro A12; SJ, S. johannesburg A28; dpi-days post immunization; Serum agglutination titre1:200, which indicate the highest dilution of the serum using agglutination test and gave more than $50 \%$ agglutination after secondary immunization.

In primary immunization, 2dpi (days post immunization), 7dpi, 14dpi sera showed no agglutination with $S$. typhimurium L1338, S. enteritidis A19, S. cerro A12, and S. johannesburg A28. But, 21dpi of primary immunization showed less than 50\% agglutination. In secondary immunization, 7dpi sera showed less than 50\% agglutination but 14dpi showed more than $50 \%$ agglutination. The agglutination titre of sera was 1:200. Cross reaction of immunological responses after immunization of the pure $37.81 \mathrm{kDa}$ protein were detected by agglutination test with 4 Salmonella serovars (Table 2). The antisera against the pure $37.81 \mathrm{kDa}$ protein of , S. typhimurium L1338, S. enteritidis A19, S. cerro A12, and S. johannesburg A 28 also showed cross reaction after secondary immunization by agglutination test. In cross reaction, the highest dilution of sera was used as 1:50 (Table 1). In each group of sera showed cross agglutination test and the highest dilution of sera were 1:50.

The protection level of $37.81 \mathrm{kDa}$ protein of 4 Salmonella serovars was shown in Table 2. According to the Table 2, group-1, ST/ST, ST/SE, ST/SC, and ST/SJ indicated $37.81 \mathrm{kDa}$ protein of $S$. typhimurium immunized chick group. This chick group was challenged by ST, (S. typhimurium) SE, (S. enteritidis) SC, (S. cerro) and SJ (S. johannesburg). The challenge doses were S. typhimurium $=5.8 \times 10^{6} ;$ S. enteritidis $=7.5 \times 10^{6} ;$ S. cerro $=7.6 \times 10^{6} ; S$. johannesburg A28 $=7.5 \times 10^{6}$. In case of homologous virulent challenge $(\mathrm{ST} / \mathrm{ST})$, the protection level was $60 \%$. But in case of heterologous virulent challenge (ST/SE, ST/SC, and ST/SJ), protection level was $40-50 \%$. The same results were found in case of group-2, SE/SE, SE/ST, SE/SC and SE/SJ indicated the 37.81 $\mathrm{kDa}$ protein of $S$. enteritidis immunized chick group. This chick group was challenged by SE, (S. enteritidis) ST, (S. typhimurium) SC, (S. cerro) and SJ (S. johannesburg). In group-3, SC/SC, SC/ST, SC/SE and SC/SJ indicated $37.81 \mathrm{kDa}$ protein of $S$. cerro immunized chick group. This chick group was challenged by SC, $(S$. Cerro) ST, (S. typhimurium) SE, (S. enteritidis) and SJ (S. johannesburg). In case of homologous virulent challenge (SC/SC) the protection level was $50 \%$. But in case of heterologous virulent challenge (SC/ST, SC/SE and SC/SJ), the protection level was $40 \%$. More or less similar results were found in case of group-4, SJ/SJ, $\mathrm{SJ} / \mathrm{ST}, \mathrm{SJ} / \mathrm{SE}$ and SJ/SC indicated $37.81 \mathrm{kDa}$ protein of S. Johannesburg immunized chick group. This chick group was challenged by SJ (S. Johannesburg), ST (S. typhimurium), SE (S. enteritidis) and SC (S. cerro).

In each case same challenged doses were used. The protection level of 4 Salmonella serovars were $50-60 \%$ recorded in case of homologous virulent challenge and $40-50 \%$ recorded in case of heterologus virulent challenge (Table 3). 
Immunological characterization of Salmonella serovars

Table 2. Cross reaction of antisera against the pure $37.81 \mathrm{kDa}$ protein by agglutination test with some Salmonella serovars

\begin{tabular}{|llllll|}
\hline Name of antisera & No. of test & \multicolumn{4}{l}{ Reciprocal of the agglutination titres to these antigen } \\
\cline { 3 - 6 } & & ST & SE & SC & SJ \\
S. typhimurium & 1 & 200 & $<50$ & $<50$ & $<50$ \\
S. enteritidis & 2 & 200 & $<50$ & $<50$ & $<50$ \\
& 1 & $<50$ & 200 & $<50$ & $<50$ \\
S. cerro & 2 & $<50$ & 200 & $<50$ & $<50$ \\
& 1 & $<50$ & $<50$ & 200 & $<50$ \\
S. johannesburg & 2 & $<50$ & $<50$ & 200 & $<50$ \\
& 1 & $<50$ & $<50$ & $<50$ & 200 \\
& 2 & $<50$ & $<50$ & $<50$ & 200 \\
\hline
\end{tabular}

ST, S. typhimurium L1338; SE, S. enteritidis A19; SC, S. cerro A28; SJ, S. johannesburg A28; 1 and 2 indicate test number.

Table 3. Protective effect of the $37.81 \mathrm{kDa}$ protein immunization, after homologous and heterologous virulent challenge with Salmonella serovars

\begin{tabular}{|c|c|c|c|c|}
\hline \multicolumn{2}{|c|}{ Challenge in immunized chick groups } & Mortality & Survivals & $\%$ of protection \\
\hline$\overline{\mathrm{ST} / \mathrm{ST}}$ & \multirow{4}{*}{ Group-1 } & 4 & 6 & 60 \\
\hline $\mathrm{ST} / \mathrm{SE}$ & & 6 & 4 & 40 \\
\hline ST/SC & & 5 & 5 & 50 \\
\hline $\mathrm{ST} / \mathrm{SJ}$ & & 6 & 4 & 40 \\
\hline Control & \multirow{6}{*}{ Group-2 } & 10 & 0 & 0 \\
\hline SE/SE & & 4 & 6 & 60 \\
\hline $\mathrm{SE} / \mathrm{ST}$ & & 6 & 4 & 40 \\
\hline $\mathrm{SE} / \mathrm{SC}$ & & 5 & 5 & 50 \\
\hline SE/SJ & & 6 & 4 & 40 \\
\hline Control & & 10 & 0 & 0 \\
\hline SC/SC & \multirow{4}{*}{ Group-3 } & 5 & 5 & 50 \\
\hline $\mathrm{SC} / \mathrm{ST}$ & & 6 & 4 & 40 \\
\hline SC/SE & & 6 & 4 & 40 \\
\hline SC/SJ & & 6 & 4 & 40 \\
\hline Control & \multirow{6}{*}{ Group-4 } & 10 & 0 & 0 \\
\hline $\mathrm{SJ} / \mathrm{SJ}$ & & 5 & 5 & 50 \\
\hline $\mathrm{SJ} / \mathrm{ST}$ & & 6 & 4 & 40 \\
\hline $\mathrm{SJ} / \mathrm{SE}$ & & 6 & 4 & 40 \\
\hline $\mathrm{SJ} / \mathrm{SC}$ & & 6 & 4 & 40 \\
\hline Control & & 10 & 0 & 0 \\
\hline
\end{tabular}

ST, S. typhimurium L1338, SE, S. entritidis A19, SC, S. cerro A12, SJ, S. johannesburg A12. Group-1 indicates the 37.81 $\mathrm{kDa}$ protein of ST (S. typhimurium) immunized chick group. This chick group was challenged by ST (S. typhimurium), SE (S. enteritidis), SC (S. cerro), and SJ (S. johannesburg). In case of other groups, the same conditions were maintained. 
In the present experiments, immunological characterization of the $37.81 \mathrm{kDa}$ surface protein from some Salmonella serovars was performed to find the suitability of this protein to use as a vaccine candidate for the control of a wide variety of Salmonella serovars. Salmonella infection results in antibody responses to a large number of antigens including LPS determinants (O-polysaccharide and core regions), porins, outer membrane proteins, lipoproteins, heat-shock proteins, flagella and fimbriae (Kuusi et al., 1979, Brown and Hormaeche., 1989, Charles et al., 1993, Cooper, 1996, Harrison et al., 1997, McSorley et al., 2000). Like other Gramnegative bacteria, $S$. typhimurium possesses an outer membrane surrounding the periplasmic space. The outer membrane contains numerous proteins reffered to as OMPs (Meyer et al., 1998). A subset of them is known as porins which form water-filled channels across the outer membrane to facilitate the transport of small hydrophilic molecules (Nikaido, 1996). S. typhimurium expresses three porins: OmpD (34 kDa); OmpF (35 $\mathrm{kDa}$ ); and OmpC (36 kDa) when grown under normal condition of Lennox broth at $37^{\circ} \mathrm{C}$ (Lee et al., 1980, Nikaido, 1985, Singh et al., 1992). OmpD is found in S. typhimurium but is absent from other Gram-negative bacteria including E. coli. OmpD is homologous with the NmpC and Lc porins in E. coli K-12 (Singh et al., 1992), both of which can only be expressed in E. coli K-12 mutants which lack normal outer membrane proteins (Riley et al., 1987). Little is known about the OmpD porin, apart from the genomic location of the ompD gene and the immunochemical and topological structure of the porin itself (Singh et al., 1996 and 1992).

Here, it was tried to establish porin-like materials which induced humoral immunity to find new proteins as candidates of vaccine for Salmonellosis control. Toward a first step, the surface proteins of $37.81 \mathrm{kDa}$ from $S$. typhimurium L1338, S. enteritidis A19, S. cerro A12 and S. johannesburg A28 were purified according to the information received from SDS-PAGE, IB and 2D-PAGE (Begum, 2005). The $37.81 \mathrm{kDa}$ protein was immunized the chicks followed by the homologous and heterologous virulent challenge experiments (Table 2). In each case, the highest protection level was recorded with the homologous virulent challenge in comparison with the heterologous virulent challenge. The protection ranges of $40-60 \%$ were recorded. Moreover, field trial should be given in different age, sex and breed groups of chicks and also in immunization protocols for the determination of better protection level.

\section{REFERENCES}

1. Andrade CM, Ferreira AGP, Silva JDC, Nascimento HJ and Silva Junior JG (1998). Chemical and immunological characterization of a low molecular weight outer membrane protein of Salmonella typhi. Microbiology and Immunology. 42 (8): 521-526.

2. Brown A and Hormaeche CE (1989). The antibody response to Salmonellae in mice and humans studied by immunoblots and ELISA. Microbial Pathogenesis 6: 445-54.

3. Begum F (2005). A $37.81 \mathrm{kDa}$ protein reacting with sera obtained from Salmonella typhimurium infected chicks in Salmonella serovars. Ph. D. thesis submitted to the Animal Health Laboratory, School of Agriculture, Ibaraki University, Ibaraki, Japan.

4. Carraminana JJ, Yanguela J, Blanco D, Rota C, Agustin A I and Herrera A (1997). Potential virulence determinants of Salmonella serovars from poultry and human sources in Spain. Veterinary Microbiology 54:375-383.

5. Charles SD, Nagaraja KV and Sivanandan V (1993). A lipid-conjugated immunostimulating complex Subunit Vaccine against Salmonella Infection in Turkeys. Avian Diseases 37: 477-484.

6. Cooper GL and Thorns CJ (1996). Evaluation of SEF 14 fimbrial dot blot and flagellar Western blot tests as indicators of Salmonella enteritidis infection in chickens. Veterinary Record 138: 149-53.

7. Harrison JA, Villarreal-Ramos, B., Mastroeni P, Demarco DHR and Hormaeche CE (1997). Correlates of protection induced by live aro-Salmonella typhimurium vaccines in the murine typhoid model. Immunology 90: 618-625.

8. Kashiwazaki M, Adachi Y and Kume T (1980). Microscopic agglutination test for antibody against Treponema hyodysenteriae. National Institute of Animal Health Q. 20: 114-115 (Japan).

9. Kuusi N, Nurminen M, Saxen H, Valtonen M and Makela PH (1979). Immunization with major outer membrane proteins in experimental Salmonellosis of mice. Infection and Immunity 25: 857-862.

10. Lee DR and Schnaitam CA (1980). Comparison of outer membrane porin proteins produced by Escherichia coli and Salmonella typhimurium. Journal of Bacteriology 142: 1019-1022.

11. Mastroeni P and Menager N (2003). Development of acquired immunity to Salmonella. Journal of Medical Microbiology 52: 453-459.

12. Matsui K and Arai T (1989). Protective immunity induced by porin in experimental mouse Salmonellosis. Microbiology and Immunology 33: 699-708.

13. McSorley SJ, Cookson BT and Jenkins MK (2000). Characterization of CD4 ${ }^{+} \mathrm{T}$ cell responses during natural infection with Salmonella typhimurium. Journal of Immunology 164: 986-993. 
14. Meyer PN, Wirmes RMR, Stahopouls C and curtiss R (1998). Virulence of Salmonella typhimurium OmpD mutant. Infection and Immunity 66: 387-390.

15. Miyazaki K, Yoshikawa Y, Akahagi K and Koshikawa N (1994). Procedure of protein purification for cDNA cloning. Bio Manual Series. In: Methodologies for protein experiments for molecular Biology. 7, Tadaomi Takenawa, Masaki Inagaki, eds, Yodo-sha, Tokyo (in Japanese). pp. 15-40.

16. Muthukkumar S and Muthukkaruppan VR (1993). Mechanism of protective immunity induced by porin lipopolysaccharide against murine Salmonellosis. Infection and Immunity 61: 3017-3025.

17. Nakamura A, Ota Y, Mizukami A, Ito T, Ngwai YB and Adachi Y (2002). Evaluation of aviguard, a commercial competitive exclusion product for efficacy and after effect on the antibody response of chickes of Sallmonella. Poultry Science 81: 1653-1660.

18. Nikaido H (1996). Outer membrane. In Neidhardt FC, Curtiss III R, Ingraham JL, Lin ECC, Low KB, Magasanik B, Reznikoff WS, Riley M, Schaechter M and Umbarger HE (eds). Escherichia coli and Salmonella. Cellular and Molecular Biology. pp. 29-47. ASM Press, Washington, D. C.

19. Nikaido H and Vaara M (1985). Molecular basis of bacterial outer membrane permeability. Microbiology Review 49: 132.

20. Riley M and Krawiec S (1987). Genome organization. In: Neidhardt FC, Ingraham JL, Low KB, Magasanik B, Schaechter M and Umbarger HE (eds). Escherichia coli and Salmonella typhimurium. Cellular and Molecular Biology. pp. 967-981. 2, American Society for Microbiology, Washington, D. C.

21. Schwartz KJ (1999). Salmonellosis. In: Diseases of swine. Straw DE, Allaire SD, Mengeling WL and Taylor DJ (eds). Iowa state Univ. Press, Ames, I A. pp. 35-551.

22. Seo KH, Holt PS, Brackett RE, Gast RK and Stone HD (2002). Mucosal humoral immunity to experimental Salmonella enteritidis infection in chicken crop. Avian Diseases 46: 1015-1020.

23. Singh SP, Miller S, Williams Y, Rudd KE and Nikaido H (1996). Immunochemical structure of the OmpD porin from Salmonella typhimurium. Microbiology 142: 3201-3210.

24. Singh SP, Sing SR, Williams YU, Jones L and Abdullah T (1995). Antigenic Determinants of the OmpC porin from Salmonella typhimurium. Infection and Immunity 63: 4600- 4605.

25. Singh SP, Upshaw Y, Abdullah T, Singh SR and Klebba PE (1992). Structural relatedness of enteric bacterial porins assessed with monoclonal antibodies to Salmonella typhimurium OmpD and OmpC. Journal of Bacteriology 174: 19651973.

26. Solano CB, Sesma M, Alvarez TJ, Humphrey CJ and Thorns CG (1998). Discrimination of strains of Salmonella enteritidis with differing levels of virulence by an in vitro glass adherence test. Journal of Clinical Microbiology 36: 674-678.

27. Tabaraie B, Sharma BK, Sharma PR, Sehgal NR and Ganguly NK (1994). Evaluation of Salmonella porins as a broad spectrum vaccine candidate. Microbiology and Immunology 38: 553-559. 